\title{
Testing of Hypocholesterolemic Effects of Ledok Added with Seaweed in Vivo
}

\author{
Ni Made Yusa* I Ketut Suter \\ Study Program of Food Science and Technology, \\ Faculty of Agriculture Technology, University of Udayana. Jimbaran Campus 80361, Badung, Bali, Indonesia
}

\begin{abstract}
Ledok is a traditional food in Nusa Penida, in form of porridge made from corn, cassava, beans, green leaves vegetables and seasoning without rice. Ledok has the potentials to be developed as a functional food, because it contents sufficient nutrients and bioactive component which is dietary fiber. The obyectives of this research is to discover the hypocholesterolemic effect of ledok added with seaweed in vivo. The experiment is conducted by Completely Randomize Design. The are four treatments which are : PO (rat group without hypercholesterol + standard feed = negative control), P1 (rat group with hypercholesterol + standard feed = positive control), P2 (rat group with hypercholesterol + standard feed + ledok $15 \%$ ) and P3 (rat group with hypercholesterol + standard feed + ledok $30 \%$ ). Every group consists of six rats. Analysis are taken before (pretest) and after (posttest) feed treatment on total cholesterol, HDL, LDL, triglyceride of rat blood. The feed treatment is given for 28 days. The research shows that there is a lowering of cholesterol total level, triglyceride and cholesterol LDL of rats blood. In the other hand there is raise in rats blood cholesterol HDL level take place by giving mix of standard feed and ledok added with seaweed. Treatment of ledok by $30 \%$ can lower total cholesterol level, triglyceride and LDL in the following order : $43.09 \%, 42.30 \%$ and $37.80 \%$ from pretest level. Meanwhile HDL level of rat blood has a raise of $172,31 \%$ from pretest level.
\end{abstract}

Keywords: ledok, hypocholesterolemic, cholesterol, triglyceride

DOI: $10.7176 /$ FSQM/90-05

Publication date:September $30^{\text {th }} 2019$

\section{Introduction}

Changes in consumption patterns of people who tend to consume foods which are high in fat and carbohydrates, but low in food fiber, has resulted in an increasing prevalence of degenerative diseases such as hyperlipidemia. This condition increases the risk of cardiovascular disease. Therefore controlling blood cholesterol concentrations is very important. One of the efforts that can be done is through diet therapy. In the diet therapy of hyperlipidemic patients, dietary fiber plays a very important role because it can reduce lipid levels. Soluble fiber can help improve glycemic control through a mechanism to delay gastric emptying. This response will also contribute to the reduction of blood lipids (McIntos et al. 2001). Consumer needs for functional food are increasing, because functional food has properties that can prevent certain diseases, beyond their nutritional functions (Subroto 2008).

Ledok is a type of porridge, one of the traditional foods in Nusa Penida, Klungkung Regency, Bali. Ledok is made from corn, cassava, beans, vegetables and herbs, without using rice (Suter et al. 2007). Ledok contains nutrients as follows: water $(71.92 \%)$, ash $(0.98 \%)$, protein $(3.15 \%)$, fat $(4.71 \%)$, crude fiber $(3.18 \%)$ and carbohydrates ( 16.05\%) (Suter et al. 2007), while instant Ledok porridge is made by adding 50\% purple sweet potato contains water $(79.01 \%)$, ash $(1.26 \%)$, protein $(6.67 \%)$, fat $(4.59 \%)$, and carbohydrate $(8.46 \%)$, and antioxidant capacity of $0.10 \%$ (GAEAC) (Suter, et al, 2013). Furthermore Suter et al. (2013) reported that instant Ledok contains soluble food fiber of $2.08 \%$, insoluble food fiber of $19.34 \%$ and total dietary fiber of $21.42 \%$.

Ledok, which is developed into a functional food in addition to its high nutritional content, also contains bioactive components such as dietary fiber which play a role in the body's physiological processes. Increased reserves of Ledok bioactive components have been carried out by Suter et al. (2013) by using purple sweet potato and by Yusa et al. (2017a) using beans. The nutrient content of instant Ledok (Ledok porridge) is $80.68 \%$ air, $0.91 \%$ ash, $7.32 \%$ protein, $1.81 \%$ fat and $9.29 \%$ carbohydrate (Suter et al. 2009), dietary fiber has the preventive nature of degenerative diseases such as diabetes, coronary heart disease and high blood pressure (Kusharto 2006 \& Subroto, 2008). Soluble dietary fiber has a hypocholesterolemic properties that can lower cholesterol levels (Stark \& Madar 1994). It is also reported that high-dietary fiber can reduce blood glucose and lipid levels in patients with type 2 diabetes mellitus (McIntos et al. 2001, Kim et al. 2008). Testing of the hypocholesterolemic effect of Ledok made with the addition of red beans has been carried out by Yusa et al. (2017a) and the results showed that giving $20 \%$ of the total mixture of standard feed and Ledok can reduce cholesterol, triglyceride and HDL serum blood levels in experimental rats. Dietary fiber can lower cholesterol levels through several mechanisms including: (1) dietary fiber inhibits the absorption of cholesterol, (2) dietary fiber lowers the availability of cholesterol so that the transfer to the blood flow is reduced, (3) dietary fiber can prevent the synthesis of cholesterol and (4) dietary fiber can increase bile excretion (Marsono 2004). 
Seaweed is one of the types of foods that contain high fiber which ranges from $25-75 \%$, useful for people with hyperlipidemia, namely abnormal cholesterol levels, where LDL concentration is higher and HDL is lower than normal (Lahaye 1991 and Murata et al. 1999) and sufferers of hypertriacylglycerolemia (Murata et al. 2002). According to MacArtain et al. (2007), species of E. cottoni, Gelidium sp. and Sargasum sp. has a fiber content of $64.43 \%, 53.05 \%$ and $56 \%$ respectively. Seaweed species that have been widely cultivated by local farmers are Eucheuma cottonii, Eucheuma spinosum and Gracilaria sp. (Herpandi et al. 2006). Because of the content of seaweed fiber, seaweed is very potential to be used as a building block material to be developed into functional food. According to Yusa et al. (2017b) the type of seaweed of Gracilaria sp. produces Ledok with the best characteristics, namely the level of preferences based on color, aroma, texture, taste and overall acceptance level is "somewhat like", fat content of $0.11 \%$, protein of $2.54 \%$, carbohydrate of $15.28 \%$, antioxidant capacity of 66.24 ppm GAEAC, IC-50 $155.32 \mathrm{mg} / \mathrm{ml}$, soluble dietary fiber of $2.80 \% \mathrm{db}$, soluble fiber food of $15.68 \% \mathrm{db}$, total food fiber of $18.40 \% \mathrm{db}$, mineral Ca of 2,620.72 ppm and Mn of 17, $18 \mathrm{ppm}$. However, it was not known whether Ledok that was made with the addition of Gracilaria sp. has hypocholesterolemic properties.

On the basis of the description above, further research is needed to examine whether Ledok made with the addition of Gracilaria seaweed has a hypocholesterolemic effect, which can reduce blood serum total cholesterol levels. The purpose of this study was to determine the hypocholesterolemic effects of the Ledok diet made with the addition of Gracilaria sp. on the experimental rats.

\section{Materials and Methods}

\subsection{Materials and Tools}

The materials used to make Ledok are: corn, corn flour, cassava, long beans, bay leaves, basil leaves, spinach leaves, garlic, salt, chili, seaweed of Gracilaria sp. and lemon. The chemicals used for the analysis are: reagent kits (cholesterol, triglycerides, and HDL). Rat feed used refers to the standards set by the American Institute of Nutrition (AIN 1993) including corn starch, CMC, soybean oil, sucrose, casein (Sigma, US), a mixture of vitamins and mineral mixtures (ICN Biomedical, Inc. Aurora, Ohio, America).

The equipment used is Ledok cooking equipment such as gas stoves, knives, blenders (Philips), and pans. The equipment used for chemical analysis includes homogenizer, vortex, small centrifugation (Hettich EBA III). Rat cages and its equipment.

\subsection{Implementation of Research}

a. Experimental design

The type of research is laboratory experimental in Wistar rats using research design namely Control Group Post Test Design (Notoatmodjo 2002 in Maligan et al. 2011). The selection of research objects and administration of treatment used the Complete Random Design method. This experiment used four treatments as follows:

P0: The group of rats without hypercholesterolemia + standard feed (negative control)

P1: The group of hypercholesterolemic rats + standard feed (positive control)

P2: The group of hypercholesterolemic rats + standard feed + Ledok $(15 \%)$

P3: The group of hypercholesterolemic rats + standard feed + Ledok $(30 \%)$

Each treatment consisted of six rats, so the total sample of all treatments was 24 Wistar rats.

b. Ways of making Ledok

The formulation and method of making Ledok in this study refers to the formulation and method of making Ledok reported by Yusa et al. (2017b) as follows. Dry Gracilaria seaweed is cleaned and sorted, then weighed as much as $100 \mathrm{~g}$, washed with water four times, then soaked in $1 \%$ citric acid solution for 24 hours. The amount of citric acid solution used is one liter or the ratio of the weight of seaweed and citric acid solution is 1: 10. After soaking, seaweed is washed four times with clean water, then drained. Next, seaweed is cut into small pieces. Vegetables (spinach leaves, basil leaves and bay leaves) are washed with water. All Ledok materials are weighed according to the formulation (Table 1). Spices, namely chili, garlic, onion, lime skin and salt mixed are then blended.

The process of making Ledok is as follows: Water is heated to boiling, then corn is added and boiled until half cooked (15 minutes), then other ingredients are added except for spinach and basil leaves which are added lastly. Boiling continues until the mature Ledok becomes porridge (20 minutes). 
Table 1. Ledok formulations (Yusa et al. 2017b)

\begin{tabular}{|c|c|c|}
\hline Num. & Ingredients & Amount (g) \\
\hline 1 & White corn & 100.00 \\
\hline 2 & Cornflour & 52.50 \\
\hline 3 & Cassava & 90.00 \\
\hline 4 & Chili & 3.00 \\
\hline 5 & Shallots & 5.00 \\
\hline 6 & Garlic & 1.50 \\
\hline 7 & Peel of kaffir lime & 0.25 \\
\hline 8 & Spinach leaf & 150 \\
\hline 9 & Beans & 107.50 \\
\hline 10 & Basil leave & 10.00 \\
\hline 11 & Bay leaf & 2.00 \\
\hline 12 & Salt & 3.00 \\
\hline 13 & Seaweed (Gracilaria sp.) & 39.00 \\
\hline 14 & Water $(\mathrm{ml})$ & 1.71 \\
\hline
\end{tabular}

c. The Making of standard feed and treatment feed

The making of standard feed refers to the manufacture of standard feed according to AIN 1993 (Reeves et al. 1993). The composition of ingredients for standard feed can be seen in Table 2. The standard feed is made as follows: All ingredients are mixed and then the mixture is made by adding $250 \mathrm{ml}$ of water. The mixture is then ground with a meat grinder to get the mill in the form of a pellet. Pellets are dried in the oven at $70^{\circ} \mathrm{C}$ until dry. Ledok powder was made according to the method reported by Yusa et al. (2017a), i.e. Ledok porridge is dried in an oven at $70^{\circ} \mathrm{C}$ until dry. The dry Ledok is then blended and sieved with a 16 mesh size sieve to obtain Ledok powder. The Ledok treatment is made by adding $15 \%$ of Ledok powder to the standard feed (P2) and adding $30 \%$ of the Ledok powder to the standard feed (P3).

Table 2. Standard feed composition (Reeves et al. 1993)

\begin{tabular}{|l|r|}
\hline \multicolumn{1}{|c|}{ Ingredients } & Standard feed $(\mathrm{g} / \mathrm{kg})$ \\
\hline Cornflour & 620.69 \\
Casein & 140.00 \\
Sucrose & 100.00 \\
Soybean oil & 40.00 \\
CMC & 50.00 \\
Mineral mix & 35.00 \\
Vitamin mix & 10.00 \\
L-cysteine & 1.80 \\
Choline bitartrate & 2.50 \\
Total & 999.99 \\
\hline
\end{tabular}

d. Bioassay

The rats used in this study were Wistar rats with a body weight ranging from 150-200 g, totaling 24 rats. Rats were placed in individual cages and adapted to the standard feed for four days. On day 5, rats were fed with hypercholesterol feed (containing $1 \%$ cholesterol and $0.01 \%$ propyl thio uracil) for two weeks, except the negative control group (P0) were not given hypercholesterol feed. During the administration of hypercholesterol feed, the rats were also given duck egg yolks in a rounded manner i.e. $0.25 \mathrm{ml}$ on the first day to the third day, $0.5 \mathrm{ml}$ on the fourth to sixth day, $0.75 \mathrm{ml}$ on the seventh to ninth day and $1 \mathrm{ml}$ on the $10^{\text {th }}$ day to $14^{\text {th }}$ day. After two weeks of administration of hypercholesterol feed, an analysis of total blood serum cholesterol was carried out to ensure that the rats had positive hypercholesterolemia. Besides that, it was also carried out an analysis of triglycerides, LDL and HDL as well as weighing the rats (pre-test). Rats were divided into three groups, each group consisting of six rats. Each group was given feed according to the treatment, namely P1, P2 and P3. The treatment test was carried out for four weeks (28 days). Analysis of lipid profiles (total cholesterol, LDL, HDL, and triglyceride levels) was carried out before the pretest feed was given and four weeks after the treatment (Post-test). Observation of feed consumption was done every day, while weighing rats was carried out every week. The bioassay procedure can be seen in Figure 1. 


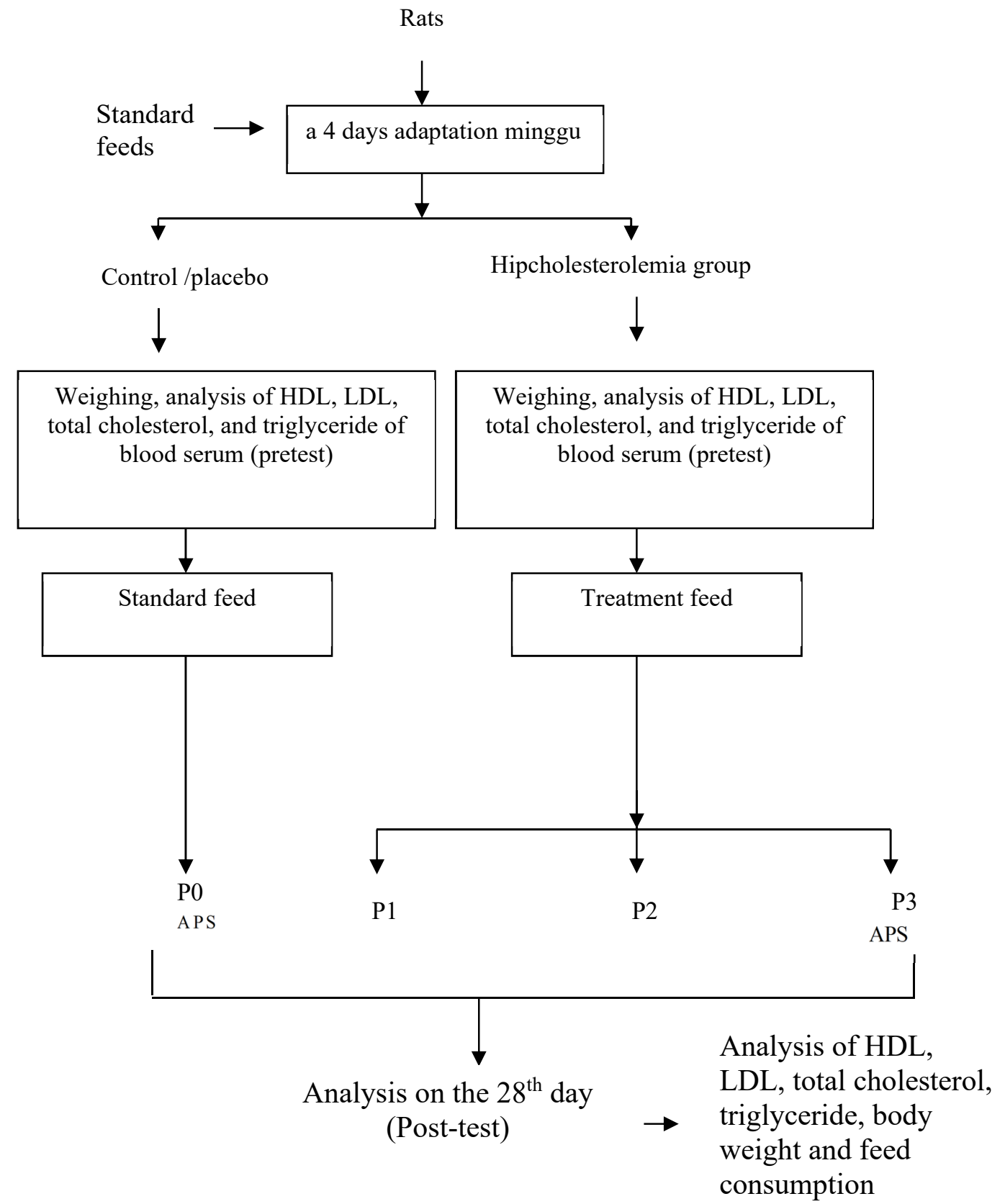

Notes :

P0 : Control (-)

$\mathrm{P} 1$ : Control $(+)$

P2 : Standard feed $+15 \%$ Ledok

P3 : Standard feed $+30 \%$ Ledok

Figure 1. Bioassay procedure

\section{e. Parameters Observed}

Parameters observed/measured in experimental animals were rat body weight, amount of feed consumed and lipid profile. Lipid profile analysis includes total serum blood cholesterol with the CHOD-PAP method (Deeg et al. 1983 and Artiss et al, 1997), HDL with the CHOD-PAP method (Lopes-Virella et al. 1997), triglycerides with the GPO-PAP method (Fossati \& Principe 1982), LDL was calculated by the [LDL-chol] equation $=[$ total chol] [HDL-chol] - [TG]/5 (Friedewald et al. 1972). Data from observations were analyzed statistically (Gomes \& Gomes 1995). 


\section{Results and Discussion}

\subsection{Feed Weight Consumed}

The average weight of feed consumed by the pretest (before given treatment feed) and post-test (after being given treatment feed) is presented in Table 3. Based on the data in Table 3, it can be seen that during the experiment there was an increase in the amount of feed consumed by rats which ranged from $85.70 \%$ to $100.70 \%$. The Increasing amount of feed consumed by rats was greater in the group of rats given the treatment feed compared to the group of rats without treatment feed. This might be caused by the treatment of food added with Ledok which caused the aroma and / or taste of feed to be more attractive to rats so that it was consumed more.

Table 3. Average value of feed weight consumed by rats

\begin{tabular}{|c|c|c|c|c|}
\hline Treatments* & $\begin{array}{c}\text { Pretest } \\
(\mathrm{g})\end{array}$ & $\begin{array}{c}\text { Posttest } \\
(\mathrm{g})\end{array}$ & $\begin{array}{c}\text { Enhancement } \\
(\mathrm{g})\end{array}$ & $\begin{array}{c}\text { Percentage } \\
(\%)\end{array}$ \\
\hline P0 & 8.67 & 16.10 & 7.43 & 85.70 \\
\hline P1 & 8.50 & 16.08 & 7.58 & 89.18 \\
\hline P2 & 8.50 & 17.06 & 8.56 & 10.70 \\
\hline P3 & 8.67 & 17.32 & 8.65 & 99.77 \\
\hline
\end{tabular}

*P0: The group of rats without hypercholesterolemia + standard feed (negative control)

P1: The group of hypercholesterolemic rats + standard feed (positive control)

P2: The group of hypercholesterolemic rats + standard feed + Ledok $(15 \%)$

P3: The group of hypercholesterolemic rats + standard feed + Ledok $(30 \%)$

\subsection{Rats' Body Weight}

The mean values of pretest and posttest rat weight are presented in Table 4. At the pretest of the hypercholesterolemic rat group, their body weight was significantly more $(\mathrm{P}<0.05)$ compared to the rat body weight of the rats without a hypercholesterol diet (negative control) (Table 4). This might be due to higher cholesterol-rich feed that causes higher body weight even though the weight of feed consumed is relatively the same. In the group of rats given additional cholesterol, the body weight of the rats was not significantly different $(\mathrm{P}>0.05)$. In the post-treatment feeding process, i.e. mixed feed between standard feed and Ledok with a ratio according to treatment, caused differences in rat body weight.

Table 4. Average value of rat body weight

\begin{tabular}{|c|c|c|c|c|}
\hline Treatments* & $\begin{array}{c}\text { Pretest } \\
(\mathrm{g})\end{array}$ & $\begin{array}{c}\text { Posttest } \\
(\mathrm{g})\end{array}$ & $\begin{array}{c}\text { Enhancement }(\mathrm{g}) \\
\text { Percentage } \\
(\%)\end{array}$ \\
\hline P0 & $194.17 \pm 9.06 \mathrm{~b}^{* *}$ & $225.3 \pm 9.35 \mathrm{~b}$ & 31.13 & 16.03 \\
\hline P1 & $218.50 \pm 12.49 \mathrm{a}$ & $250.2 \pm 13.04 \mathrm{a}$ & 31.70 & 14.51 \\
\hline P2 & $221.67 \pm 12.24 \mathrm{a}$ & $257.2 \pm 12.92 \mathrm{a}$ & 35.53 & 16.03 \\
\hline P3 & $211.17 \pm 7.11 \mathrm{a}$ & $245.3 \pm 7.84 \mathrm{a}$ & 34.13 & 16.16 \\
\hline
\end{tabular}

*P0: The group of rats without hypercholesterolemia + standard feed (negative control)

P1: The group of hypercholesterolemic rats + standard feed (positive control)

P2: The group of hypercholesterolemic rats + standard feed + Ledok $(15 \%)$

P3: The group of hypercholesterolemic rats + standard feed + Ledok $(30 \%)$

**The same letter behind the average value in the same column showed no significant difference $(\mathrm{P}>0,05)$

based on DMRT.

In the hypercholesterol group of rats the body weight was significantly different $(\mathrm{P}<0.05)$, which was higher than the rat body weight of rats without hypercholesterol, but among the hypercholesterolemic rat group given standard feed and feed mixture of Ledok, the rat body weight was not significant $(\mathrm{P}>0.05)$ i.e. ranged between $245.3 \mathrm{~g}-257.2 \mathrm{~g}$. There was an increase in rat body weight during the experiment which ranged from $14.51 \%$ to $16.16 \%$ to the pretest rat body weight due to an increase in the amount of feed consumed by rat during the experiment (Table 3).

\subsection{Total Cholesterol Levels of Rats' Blood}

The average value of total cholesterol levels in pretest and posttest rats' blood is presented in Table 5. At pretest, the administration of hypercholesterol diet showed significant differences $(\mathrm{P}<0.05)$, namely total blood cholesterol levels of rats in the group without being given a lower hypercholesterol diet compared to those given a hypercholesterol diet. Total cholesterol levels of rats given a hypercholesterol diet, among groups of rats given standard feed and groups of rats fed with Ledok mixed feed were not significantly different $(\mathrm{P}>0.05)$ which ranged between $205.53 \mathrm{mg} / \mathrm{dl}$ and $206.74 \mathrm{mg} / \mathrm{dl}$. Based on the data in Table 5 on the posttest, it can be seen that the total blood cholesterol level of rats in the rats given the treatment feed was significantly different $(\mathrm{P}<0.05)$, which was lower than the group of rats without given treatment feed (positive control). If it is compared between pretest and post-test, there was a decrease in total blood cholesterol levels of rats in the group of rats given standard feed 
mixed with $15 \%$ and $30 \%$ Ledok, which were $32.39 \%$ and $43.09 \%$ respectively, whereas in the rat group without given treatment feed (positive control), there was a slight increase in total cholesterol levels of $2.74 \%$.

Table 5. Average value of total cholesterol levels in rats' blood

\begin{tabular}{|c|c|c|c|c|}
\hline Treatments* & $\begin{array}{c}\text { Pretest } \\
(\mathrm{mg} / \mathrm{dl})\end{array}$ & $\begin{array}{c}\text { Posttest } \\
(\mathrm{mg} / \mathrm{dl})\end{array}$ & $\begin{array}{c}\text { Enhancement/Reducti } \\
\text { on }(\mathrm{mg} / \mathrm{dl})\end{array}$ & $\begin{array}{c}\text { Percentage } \\
(\%)\end{array}$ \\
\hline P0 & $74.13 \pm 2.40 \mathrm{~b}^{* *}$ & $75.49 \pm 2.88 \mathrm{~d}$ & 1.36 & 1.83 \\
\hline P1 & $206.74 \pm 4.49 \mathrm{a}$ & $212.40 \pm 3.98 \mathrm{a}$ & 5.66 & 2.74 \\
\hline P2 & $206.14 \pm 3.02 \mathrm{a}$ & $139.37 \pm 6.40 \mathrm{~b}$ & -66.77 & -32.39 \\
\hline P3 & $205.53 \pm 3.81 \mathrm{a}$ & $116.96 \pm 5.30 \mathrm{c}$ & -88.57 & -43.09 \\
\hline
\end{tabular}

*P0: The group of rats without hypercholesterolemia + standard feed (negative control)

P1: The group of hypercholesterolemic rats + standard feed (positive control)

P2: The group of hypercholesterolemic rats + standard feed + Ledok $(15 \%)$

P3: The group of hypercholesterolemic rats + standard feed + Ledok $(30 \%)$

**The same letter behind the average value in the same column showed no significant difference $(\mathrm{P}>0,05)$

based on DMRT.

The decrease in total cholesterol levels of rat blood in the group of rats given Ledok may be due to the presence of dietary fiber in Ledok. Dietary fiber can reduce blood cholesterol levels (Rusilanti \& Kusharto 2007). Ledok made with the addition of Gracilaria sp. seaweed containing a total dietary fiber of $18.40 \%$ which includes soluble dietary fiber of $2.80 \%$ and insoluble dietary fiber of $15.68 \%$ (Yusa, et al., 2017b). In foods containing high dietary fiber, there is an increase in excretion of fats, bile acids and cholesterol (Anderson et al. 1994). Dietary fiber can bind blood cholesterol and released through feces so that blood cholesterol decreases (Wisaniyasa 2017).

\subsection{Rat Blood Triglyceride Levels}

The average data of pretest and posttest rat blood triglyceride levels are presented in Table 6. Rat blood triglyceride levels in hypercholesterolemic group of rats were significantly different $(\mathrm{P}<0.05)$, which was higher than rat blood triglyceride levels in groups of rats without hypercholesterolemia. Blood triglyceride levels in hypercholesterolemic rats ranged from $125.90 \mathrm{mg} / \mathrm{dl}$ and $129.45 \mathrm{mg} / \mathrm{dl}$. Based on the data in Table 6 on the post-test, it can be seen that the rat blood triglyceride levels in the rats given the treatment feed of the mixture of standard feed and 15\% and 30\% Ledok were significantly different $(\mathrm{P}<0.05)$ which was lower than the rats without treatment feed (positive control).

Table 6. Average rat blood triglyceride levels

\begin{tabular}{|c|l|l|c|c|}
\hline Treatments* & \multicolumn{1}{|c|}{$\begin{array}{c}\text { Pretest } \\
(\mathrm{mg} / \mathrm{dl})\end{array}$} & Posttest $(\mathrm{mg} / \mathrm{dl})$ & $\begin{array}{c}\text { Enhancement/Reduction } \\
(\mathrm{mg} / \mathrm{dl})\end{array}$ & $\begin{array}{c}\text { Percentage } \\
(\%)\end{array}$ \\
\hline P0 & $67.60 \pm 1.98 \mathrm{c}^{* *}$ & $68.80 \pm 1.60 \mathrm{c}$ & 1.20 & 1.77 \\
\hline P1 & $129.45 \pm 2.51 \mathrm{a}$ & $132.05 \pm 3.45 \mathrm{a}$ & 2.60 & 2.01 \\
\hline P2 & $127.21 \pm 1.41 \mathrm{ab}$ & $86.04 \pm 3.96 \mathrm{~b}$ & -41.17 & -32.36 \\
\hline P3 & $125.90 \pm 2.84 \mathrm{~b}$ & $72.65 \pm 5.30 \mathrm{c}$ & -53.25 & -42.30 \\
\hline
\end{tabular}

*P0: The group of rats without hypercholesterolemia + standard feed (negative control)

P1: The group of hypercholesterolemic rats + standard feed (positive control)

P2: The group of hypercholesterolemic rats + standard feed + Ledok $(15 \%)$

P3: The group of hypercholesterolemic rats + standard feed + Ledok $(30 \%)$

**The same letter behind the average value in the same column showed no significant difference $(\mathrm{P}>0,05)$ based on DMRT.

If it is compared between pretest and post-test, there was a decrease in rat blood triglyceride levels in the group of rats given standard feed mixed with $15 \%$ and $30 \%$ Ledok which were $32.36 \%$ and $42.30 \%$ respectively, whereas in the rat group without treatment feed (positive control) had a slight increase in triglyceride levels of $2.01 \%$. This decrease in triglyceride levels may be due to the effect of dietary fiber on Ledok. Consumption of dietary fiber that meets the needs can increase fat excretion through feces (Brown et al. 1999). Dietary fiber can bind fat, so that lower fat absorption also means lowering blood triglyceride levels.

\subsection{HDL Level of Rat Blood}

The average HDL levels of pretest and post-test rat blood are presented in Table 7. The HDL levels of rat blood in hypercholesterolemic group of rats were significantly different $(\mathrm{P}<0.05)$ which was lower than the HDL level of rat blood in the rat group without hypercholesterolemia. HDL levels of rat blood in hypercholesterolemic rats ranged from $24.49 \mathrm{mg} / \mathrm{dl}$ and $25.51 \mathrm{mg} / \mathrm{dl}$. Based on the data in Table 7 on the post-test, it can be seen that the HDL levels of rat blood in the group of rats given treatment feed with a mixture of standard feed and Ledok of $15 \%$ and $30 \%$ were significantly different $(\mathrm{P}<0.05)$ which was higher than the group of rats without treatment feed (positive control). 
Table 7. Mean value of HDL levels of rat blood

\begin{tabular}{|c|l|l|c|c|}
\hline Treatments* & Pretest $(\mathrm{mg} / \mathrm{dl})$. & Posttest $(\mathrm{mg} / \mathrm{dl})$. & $\begin{array}{c}\text { Enhancement/Reduction } \\
(\mathrm{mg} / \mathrm{dl})\end{array}$ & $\begin{array}{c}\text { Percentage } \\
(\%)\end{array}$ \\
\hline P0 & $82.54 \pm 3.24 \mathrm{a}^{* *}$ & $80.68 \pm 2.80 \mathrm{a}$ & -1.86 & -2.25 \\
\hline P1 & $25.51 \pm 1.65 \mathrm{~b}$ & $24.27 \pm 1.24 \mathrm{~d}$ & -1.24 & -4.86 \\
\hline P2 & $25.17 \pm 0.96 \mathrm{~b}$ & $49.23 \pm 3.11 \mathrm{c}$ & 24.06 & 95.59 \\
\hline P3 & $24.49 \pm 2.19 \mathrm{~b}$ & $66.69 \pm 2.67 \mathrm{~b}$ & 42.20 & 172.31 \\
\hline
\end{tabular}

*P0: The group of rats without hypercholesterolemia + standard feed (negative control)

P1: The group of hypercholesterolemic rats + standard feed (positive control)

P2: The group of hypercholesterolemic rats + standard feed + Ledok $(15 \%)$

P3: The group of hypercholesterolemic rats + standard feed + Ledok $(30 \%)$

**The same letter behind the average value in the same column showed no significant difference $(\mathrm{P}>0,05)$ based on DMRT.

If it is compared between pretest and post-test, there was an increase in HDL levels of rat blood in the group of rats given standard feed mixed with Ledok of $15 \%$ and $30 \%$, which were $95.59 \%$ and $172.31 \%$ respectively, whereas in the rat group without treatment feed (positive control) decreased slightly in HDL levels by $4.86 \%$. This increase in HDL levels may be related to a decrease in rat blood triglyceride levels.

\subsection{LDL Level of Rat Blood}

The mean LDL levels of pretest and post-test blood rats are presented in Table 8. At the pretest of LDL blood levels of rats in hypercholesterolemic group of rats were significantly different $(\mathrm{P}<0.05)$ which was higher than LDL blood levels of rats in the group of rats without hypercholesterolemia. LDL levels of rat blood in hypercholesterolemic rats ranged from $74.74 \mathrm{mg} / \mathrm{dl}$ and $76.47 \mathrm{mg} / \mathrm{dl}$. Based on the data in Table 8 on the posttest, it can be seen that the LDL levels of rat blood in the rats given the treatment feed with a mixture of standard feed and Ledok of 15\% and 30\% were significantly different $(\mathrm{P}<0.05)$, which was lower than the rat group without given treatment feed (positive control). If it is compared between pretest and post-test, there was a decrease in LDL blood levels of rats in the group of rats given standard feed mixed with Ledok of $15 \%$ and $30 \%$, which were $26.99 \%$ and $37.80 \%$ respectively, whereas in the rats group without treatment feed (positive control), there was an increase in LDL levels of $2.75 \%$.

Table 8. Average value of LDL levels of rat blood

\begin{tabular}{|c|l|c|c|c|}
\hline Treatments* & Pretest $(\mathrm{mg} / \mathrm{dl})$ & Posttest $(\mathrm{mg} / \mathrm{dl})$ & $\begin{array}{c}\text { Enhancement/Reduction } \\
(\mathrm{mg} / \mathrm{dl})\end{array}$ & $\begin{array}{c}\text { Percentage } \\
(\%)\end{array}$ \\
\hline P0 & $23.65 \pm 2.12 \mathrm{~b}^{* *}$ & $24.94 \pm 2.26 \mathrm{~d}$ & 1.29 & 5.45 \\
\hline P1 & $76.47 \pm 1.43 \mathrm{a}$ & $78.57 \pm 2.46 \mathrm{a}$ & 2.10 & 2.75 \\
\hline P2 & $75.78 \pm 1.50 \mathrm{a}$ & $55.33 \pm 2.00 \mathrm{~b}$ & -20.45 & -26.99 \\
\hline P3 & $74.74 \pm 1.69 \mathrm{a}$ & $46.49 \pm 2.42 \mathrm{c}$ & -28.25 & -37.80 \\
\hline
\end{tabular}

*P0: The group of rats without hypercholesterolemia + standard feed (negative control)

P1: The group of hypercholesterolemic rats + standard feed (positive control)

P2: The group of hypercholesterolemic rats + standard feed + Ledok $(15 \%)$

P3: The group of hypercholesterolemic rats + standard feed + Ledok $(30 \%)$

*The same letter behind the average value in the same column showed no significant difference $(\mathrm{P}>0,05)$ based on DMRT.

Decreased blood LDL levels in the group of rats given the Ledok mixed diet may be due to the effects of dietary fiber found in Ledok. As discussed earlier, the feeding with Ledok can reduce total blood cholesterol levels in rats. Decreasing total cholesterol levels means there is also a decrease in blood LDL levels (Indra \& Panunggal 2015).

\section{Conclusions}

This research can be summarized as follows:

1. The feeding with mixed feed namely standard feed and Ledok added with seaweed of Gracilaria sp. resulted in an increase in both the amount of feed consumed and the body weight of rats during the 28 day experiment.

2. Feeding with mixed feed namely standard feed and Ledok added with seaweed of Gracilaria sp. effect on total cholesterol, triglycerides, LDL and HDL levels, in which there was a decrease in the levels of total cholesterol, triglycerides and LDL in rat blood, while HDL levels in rat blood increased.

3. Feeding with mixed feed namely standard feed and 30\% Ledok can reduce total cholesterol, triglyceride and LDL levels in a row by $43.09 \%, 42.30 \%$ and $37.80 \%$ from the pretest level, while the HDL level of rat blood increased by $172.31 \%$ from the pretest level. 
From the research results, it can be suggested that Ledok which is made by adding seaweed Gracilaria sp. can be used as a diet for people who experience hyperlipidemia disorders.

\section{Acknowledgement}

I am grateful to the Dean of the Faculty of Agricultural Technology of Udayana University who has provided financial assistance for the implementation of this research through a Work Agreement (SPK) No: 956 / UN14.2.12.II / PN.01.00.00 / 2018, dated April 5, 2018.

\section{References}

Anderson, J.W., Jones, A.E. \& Riddell-Mason, S. (1994), "Ten Difference Dietary Fiber Have Significantly Different Effects on Serum and Liver Lipid of Cholesterol Fed Rats", J. Nutr. 124, 78-83.

Artiss, J.D. \& Zak, B. (1997), "Measurement of Cholesterol Concentration", In Rifai N., Warnick, G.R., \& Dominiczak, M.H. Eds. Hanbook of Lipoprotein Testing Washington, ACCC Press , $99-114$.

Brown, L. Rosner, B., Willett, W. W. \& Frank M Sacks, F. M. (1999), "Cholesterol-lowering Effects of Dietary Fiber: a meta-analysis 1,2”, Am J Clin Nutr. 69, 30-42.

Deeg, R. \& Ziegenhorn, J. (1983), "Kinetic Enzimatic Method for Automated Determination of Total Cholesterol in Serum", Clin. Chem. 29, $1978-1802$

Fossati, P. \& Principe, L. (1982), "Serum Triglycerides Determined Colorimetrically with an Enzyme that Produces Hydrogen Peroxide", Clin. Chem. 28, 2077 - 2080

Friedewald, W.T., Revy L.I., \& Fredrickson, D.S. (1972), "Estimation of the Concentration of Low Density Lipoprotein Cholesterol in Plasma, Without Use of the Preparative Ultracentrifuge", Clin. Chem. 28, 499 502.

Gomes, K.A. \& Gomes, A.T. (1995), Terjemahan Sjamsudin, E. \& Baharsyah, J.S. "Prosedur Statistik Untuk Penelitian Pertanian", UI Press. Jakarta.

Herpandi, M., A., Tutik, W.\& Nurheni, S.P. (2006), "Perubahan Profil Lipida, Kolesterol Digesta dan Asam Propionat pada Tikus dengan Diet Tepung Rumput Laut”, Jurnal Teknol. dan Industri Pangan 17 (3), 227 $-232$.

Indra, I.R. \& Panunggal, B. (2015), "Pengaruh Pemberian Selai Kacang Tanah dengan Substitusi Bekatul Terhadap Kadar Kolesterol HDL dan LDL Tikus Hiperkolesterolemia”, J.of Nutr.College. 4 (2)

Kim, M.S., Kim, J.Y., Choi, W.H., \& Lee, S.S. (2008), "Effect of Seaweed Suplementation on Blood Glucose Concentration, Lipid Profile and Antioxidant Enzyme Activities in Patient with Type 2 Diabetes mellitus", Nutrition Research and Practice 292, 62 - 67

Kusharto, C. M. (2006), "Dietary Fiber and Its Role for Health”, J. Gizi dan Pangan 1(2), 45-54.

Lahaye, M. (1991), "Marine Alga as Sources of Fibre Determination of Soluble and Insoluble Dietary Fiber Contents in Some Sea Vegetable”,,J. Science Food Agri. 54, 587 - 594.

Lopes-Virella, M.F., Stone, P., Ellis, S. \& Cowell, J.A. (1977), "Cholesterol Determination in High Density Lipoprotein Separated by Three Defferent Methods", Clin. Chem. 23, $882-884$.

Maligan, J.M., Estiasih, T., Sunarharum, W.B.\& Rianto. T. (2011), "Efek Hipokolesterolemik Tepung Umbi Gadung (Dioscorea hispida Dennst) pada Tikus Wistar Jantan Yang Diberi Diet Hiperkolesterol”, J. Tekno. Pertanian 12 (2), 91-99.

Marsono, Y. (2004), "Serat Pangan Dalam Persepektif Ilmu Gizi”, Pidato Pengukuhan Jabatan Guru Besar pada Fakultas Teknologi Pertanian Universitas Gajah Mada, Yoyakarta.

MacArtain, P., Christopher, I.R., Grill, Mariel, B., Ross, C. \& Ian, R.R. (2007), "Nutritional Value of Edible Seaweeds", Nutrition Reviews 65 (12), 535 - 543.

MacIntosh, M., \& Carla, M.(2001), "A Diet Containing Food Rich in Soluble and Insoluble Fiber Improves Glycemic Control and Reduce Hyperlipidemia among Patiens with Type 2 Diabetes Mellitus", Nutrition Review 59 (2), 52 - 55

Murata, M., Kenji, I. \& Hiroaki, S. (1999)< "Hepatic Fatty Acid Oxidation Enzyme Avtivities are Stimulated in Rats Fed the Brown Seawed Undaria pinnatifida (Wakame)", J. Nutr. 129 (1),146 - 151.

Murata, M., Sano,Y. Ishihara, K. \& Uchida, M. (2002), "Dietary Fish Oil and Undaria pinnatifida (wakame) Synergistically Decrease rat Serum and Liver Triacylglycero", J. Nutr. 132, $742-747$.

Reeves, P.G., Nielsen, F.H. \& Fahey, G.C. (1993), “AIN-93 Purified Diets for Laboratory Rodents”, Final Report of the American institute of Nutrition Ad Hoc writing Committee on the Reformulation of AIN-76 Rodent Diet. J. Nutr. 123, 1939-1953

Rusilanti \& Kusharto, C. M. (2007), “Sehat Dengan Makanan Berserat”, Jakarta: Agromedia.

Stark, A. \& Madar, Z. (1994), “Dietary Fiber”, In Functional Foods. Designer Foods, Pharmafoods, Nutraceuticals, Goldberg, I. (Ed.). Chapman \& Hall, New York, 183-201.

Subroto, M.A. (2008), "Real Food, True Health, Makanan Sehat Untuk Hidup Lebih Sehat", PT Agro Media Pustaka, Jakarta. 
Suter, I K., Wijaya, I M.A. S., Agung, I G.N., Yusa, Ni M. \& Suryawantha, I B. K. (2007), "Studi Pengembangan Produk Olahan dari Umbi-umbian dan Jagung Dalam Rangka Diversifikasi Pangan”, Kerjasama Dinas Pertanian Tanaman Pangan Provinsi Bali dengan Pusat Kajian Makanan Tradisional Lembaga Penelitian Universitas Udayana, Denpasar.

Suter, I K., Sugitha, I M., Putra, I N.K., Suparthana, I P., Yusa, Ni M., Nocianitri, K. A.\& Wisaniyasa, Ni W (2009), “ Optimasi Proses dan Metode Pengemasan Ledok Instan”, Pusat Kajian Makanan Tradisional Lembaga Penelitian Universitas Udayana bekerjasama dengan Badan Pemberdayaan Masysrakat dan Pemerintahan Desa Provinsi Balai., Denpasar.

Suter, I K., Yusa, Ni M., Yusasrini, N.L. A.\& Nocianitr, K.A., (2013), "Peningkatan Sifat Sensorik, Zat Gizi dan Daya Anti Oksidan Ledok Instan Dengan Penambahan Ubi Jalar Ungu”, Proseding Seminar Nasional PS.Teknologi Industri Pertanian Bekerja sama dengan Assosiasi Profesi Teknologi Agro Industri (APTA).

Wisaniyasa, N. W. (2017), "Karakterisasi Sifat Fungsional dan Kimia Tepung Kecambah Kacang Gude (Cajanus cajan (L) Millps.) dan Efek Fisiologisnya Sebagai dasar Pengembanagna Pangan Fungsional” Disertasi. Program Pascasarjana Universitas Udayana,. Denpasar.

Yusa, Ni M., Suter, I K. \& Yusasrini, N.L.A.(2017a), “ The Functional Properties of Ledok Added With Red Beans Viewed from in Vivo Hipocholesterolemic Effects", Food Science and Quality Mangement 61, 62-66

Yusa, Ni M., Sugitha, I M., Putra, I.N.K. \& Sujaya, I.N. (2017b), "The Characteristics of Ledok Which is Added with Seaweed",. Food Science and Quality Mangement 68: 23-28. 